\title{
ANTI-INFLAMMATORY POTENTIAL OF MICROEMULSION AND PURE BULLFROG OIL IN MUSCLE INJURY
}

\author{
POTENCIAL ANTI-INFLAMATÓRIO DO ÓLEO DERÃ-TOURO PUROE EM MICROEMULSÃO \\ EMLESÃOMUSCULAR
}

Original Article

ARTIGo ORIGINAL Artículo Original

\section{POTENCIAL ANTIINFLAMATORIO DEL ACEITE PURO DERANA TORO YEN MICROEMULSIÓN ENLESIÓN MUSCULAR}

\author{
André Luiz Silva Davim \\ (Doctor) \\ Tereza Neuma de Castro Dantas² \\ (Doctor) \\ Diego Filgueira Albuquerque ${ }^{1}$ \\ (Nurse) \\ Márcia Rodrigues Pereira² \\ (Doctor) \\ Laíse Beatriz Trindade da Silva \\ Queiroz ${ }^{1}$ (Graduation in Nutrition) \\ Leandro Moura de Freitas ${ }^{1}$ \\ (Biologist) \\ 1. Centro Universitário do Rio \\ Grande do Norte (UNI-RN), \\ Departamento de Morfologia, \\ Laboratório de Produtos Naturais \\ e Inflamação (LAPNIN), Natal, \\ RN, Brazil. \\ 2. Universidade Federal do Rio \\ Grande do Norte (UFRN), \\ Instituto de Química, Laboratório \\ de Tecnologia de Tensoativos, \\ Natal, RN, Brazil.
}

\section{Correspondence:}

André Luiz Silva Davim Rua Prefeita Eliane Barros, 2000, Tirol, Natal, RN, Brazil. 59014-545. anatomia@unirn.edu.br

\begin{abstract}
Introduction: Every day science seeks new ways to treat various diseases through drugs that are efficient and viable. Thus, therapeutic alternatives that meet such demand are targets of study. Microemulsions are one of these new alternatives due to their peculiar pharmacodynamic and pharmacokinetic characteristics. Objective: The aim of this study was to analyze the anti-inflammatory potential of microemulsion and pure bullfrog oil using an experimental model of muscle injury. Methods: Male Swiss mice were divided into three groups: control, microemulsion and pure bullfrog oil. After the pre-treatment, a muscle injury was induced in the animals'leg and subsequently evaluations were carried out in the horizontal extent of edema and compared between the groups at predetermined times. Following evaluation of muscle injury, dissection of the right gastrocnemius muscles was performed for histological analysis. Results: The microemulsion and pure bullfrog oil showed good anti-inflammatory activity, acting similarly in reducing edema during the first two hours, but without statistical significance from the 3 rd to the 24th hour after induction. The histological analysis revealed that the muscle tissue of the animals treated with the microemulsion presented mild cellular infiltrate and little wear of muscle fibers when compared with the muscular tissue of animals treated with the pure bullfrog oil. The histological analysis of the hepatic tissue showed signs of injury in the liver lobes of the pure bullfrog oil group, not observed in the microemulsion group. Conclusion: The microemulsion showed good anti-inflammatory potential in the acute phase of the inflammatory response, reducing the formation of edema and preserving muscle tissue against the occurrence of lesions and without inducing injury in hepatic tissue.
\end{abstract}

Keywords: inflammation; fats; liver.

\section{RESUMO}

Introdução: Todos os dias, a ciência busca novas formas de tratar diversas doenças por meio de fármacos que sejam eficientes e viáveis. Desse modo, as alternativas terapêuticas que atendam tal demanda são alvos de estudo. As microemulsões são uma dessas novas alternativas, em razão de suas características farmacodinâmicas efarmacocinéticas peculiares. Objetivo: O objetivo deste estudo foi analisar o potencial anti-inflamatório do óleo de rä-touro puro eem microemulsão usando um modelo experimental de lesão muscular. Métodos: Foram utilizados camundongos machos da linhagem Swiss, divididos em três grupos: controle, microemulsão e óleo de rã-touro puro. Após o pré-tratamento, induziu-se uma lesão muscular na perna dos animaise, em seguida, foram realizadas avaliações da extensão horizontal do edema e comparadas entre os grupos em tempos predeterminados. Depois da avaliação da lesão muscular, realizou-se a dissecção dos músculos gastrocnêmios direitos para análise histológica. Resultados: A microemulsão e o óleo de rã-touro puro apresentaram boa atividade anti-inflamatória, atuando de forma semelhante na redução do edema durante as primeiras duas horas, porém sem significância estatística da $3 a$ até a 24 a hora depois da indução. Nas análises histológicas, observou-se que no tecido muscular dos animais tratados com a microemulsão houve discreta presença de infiltrado celular e pouco desgaste das fibras musculares quando comparado com o tecido muscular dos animais tratados com o óleo de rã-touro puro. A análise histológica do tecido hepático mostrou sinais de lesão nos lobos hepáticos dos animais do grupo óleo de rã-touro puro, não observada nos animais do grupo microemulsão. Conclusão: A microemulsão apresentou bom potencial anti-inflamatório na fase aguda da resposta inflamatória, atenuando a formação de edema e preservando o tecido muscular contra a ocorrência de lesões e sem indução de lesão no tecido hepático.

Descritores: inflamação; gorduras; fígado.

\section{RESUMEN}

Introducción: Todos los días, la ciencia busca nuevas formas para tratar diversas enfermedades por medio de fármacos eficientes y viables. Así, las alternativas terapéuticas que puedan atender esta demanda son objeto deestudio. Las microemulsiones son una de estas nuevas alternativas debido a sus características farmacodinámicas y farmacocinéticas únicas. Objetivo: El objetivo de este estudio fue analizar el potencial antiinflamatorio de la microemulsión yel aceite puro de la rana toro utilizando un modelo experimental de lesión muscular. Métodos: Fueron utilizados ratones machos de la cepa Swiss, divididos en tres grupos: control, microemulsión y aceite puro de la rana toro. Después del pretratamiento, se ha creado una lesión muscular en las piernas de los animales y luego se realizaron evaluaciones de la extensión horizontal del edema y comparadas entre 
grupos en momentos predeterminados. Después de la evaluación de la lesión muscular, se llevó a cabo la disección de los músculos gastrocnemios derechos para el análisis histológico. Resultados: La microemulsión y el aceite de rana toro puro mostraron buena actividad antiinflamatoria, actuando de manera similar para reducir el edema durante las primeras dos horas, pero sin significación estadística desde la tercera hasta la 24. hora después de la inducción. Los análisis histológicos revelaron queel tejido muscular de los animales tratados con microemulsión presentó presencia moderada de infiltrado celular y poco desgaste de las fibras musculares en comparación con el tejido muscular de los animales tratados con el aceite de rana puro. El análisis histológico del tejido hepático mostró señales de lesión en los lóbulos del hígado de los animales del grupo aceite puro de rana toro, que no fueron observadas en los animales del grupo microemulsión. Conclusión: La microemulsión mostró un buen potencial antiinflamatorio en la fase aguda de la respuesta inflamatoria, la atenuación de la formación de edemay la preservación del tejido muscular en contra de la aparición delesionesy sin inducción de lesión en el tejido hepático.

Descriptores: inflamación; grasas; hígado.

\section{INTRODUCTION}

Current drugs are delivered through conventional pharmaceutical formulas that typically cannot reach the adequate concentrations at the target tissue, due to biological barriers that ultimately expose other tissues to the toxic effects of the medication. For their peculiar characteristics, such as viscosity, ease of preparation, high pharmaceutical solubility and high bio availability, beside low toxicity levels, microemulsions are presented as new alternatives ${ }^{1}$. Microemulsions are thermodynamically stable and isotropically clear of two immiscible liquids (oil/water) ${ }^{1}$. The term microemulsion (ME) has been used to define systems of micro heterogenic phases of up to five constituents: water, oil phase, tensoactive and cotensoactive. From the structural point of view, microemulsions can be of the following types: oil in water $(\mathrm{O} / \mathrm{W})$, water in oil (W/O) or bi-continuous ${ }^{2}$. In this study, water in oil (W/O) microemulsion was used, composed by the aqueous phase (ethanol at 70\%), soy lecithin as the tensoactive and bullfrog oil (FO) as the oily phase. The lecithin is used as a tensoactive on the preparation of microemulsions for their lipophilic and hydrophilic properties and for the balance between these properties and a strong tendency to form liquid crystals ${ }^{1}$. The active ingredient tested in this study and transported in a microemulsion was the bull-frog oil (FO). This oil has already been broadly utilized by the population - sometimes indiscriminately - for treatment of several ailments. The FO is obtained from the bull-frog's (Rana catesbeiana) fat tissue, a frog species native to eastern North America, but currently cultivated in several regions of the world. There is presently a growing investigation of possible therapeutic properties for $\mathrm{FO}$, due to the presence of polyunsaturated fatty acids (PUFA), omega-3 and omega-6, in its composition $^{3}$. The oil proportions of polyunsaturated fatty acids on bull-frog oil are $31.7 \%$ of oleic acid (omega-6) and $12.9 \%$ of linolenic acid (omega-3) 4 . Some studies have been conducted to evaluate their power on anti-inflammatory processes ${ }^{5-8}$; however, the results are still not very conclusive for proving this potential. The increased consumption of PUFA by the human being brings substantial changes to the organism, such as increased membrane fluidity, an influence on the expression of membrane receptors, nutrient transport and signs of transduction, acting on cellular growth ${ }^{9}$. PUFA and the products derived from its cellular metabolism may modulate the kinases activities involved on the NF-kB activities (Kappa B nuclear factor), which is an inflammation factor activated by the phosphorylation of $\mathrm{kB}$ protein. As a consequence of this activation, the NF-kB migrates to the nucleus of the cell, connecting to the DNA sequences ( $k B$ sites) which are located on the regions promoting genes related to apoptosis, cellular adhesion, immune response, inflammation, cellular stress and tissue remodeling. It is believed that PUFA can be relevant to the inflammatory process for being connected to the suspension of factors like NF-kB, modulating its activity and diminishing the tissue wear due to the liberation of cytokines ${ }^{10}$. As it's a substance rich in fatty acids, the possibility that the administration of pure FO and in microemulsion may cause hepatic overload must be analyzed.
As previously said, microemulsion is a new system for drug release, which raises the hypothesis that it may be less metabolically offensive to the liver when compared with the pure bullfrog oil. The changes on the composition of fatty acids in liver tissues may influence the lipid metabolism and regulate inflammatory processes in mammals ${ }^{11}$. However, when it comes to the ingestion of fatty acids, attention is required for the possibility of fat accumulation in the organ, which may predispose the individual to a situation of hepatic steatosis, first event of non-alcoholic disease on fat liver. It becomes important to analyze hepatic lipids not only as hepatotoxic factors, but as markers of the hepatic exposure to free fatty acids, possible inducers of hepatotoxicity. The objective of this study was to investigate if the microemulsion of bullfrog oil may act as a modulator of the activities triggered by the muscular inflammation, in an effort to avoid the exacerbated wear of the tissue (injury), providing it a better regeneration, as well as if it may contribute for the preservation of the liver, avoiding its overburden.

\section{MATERIALS AND METHODS}

To obtain and determine the microemulsion, the study of ternary diagrams was required to determine the regions (points) of the microemulsion. The diagram was obtained from the proportions of oil phase and tensoactive, titrated with alcohol solution at 70\%, used as the aqueous phase, as represented on Figure 1.

A microemulsion composed of $90 \%$ of oil phase, $5 \%$ tensoactive (soy lecithin) and 5\% aqueous phase (water/ethanol 70\%) was used. 18 male mice from the Swiss lineage, Mus musculus species were used and randomly selected, separated in three groups $(n=6)$ : one control group (saline) and two experimental groups (microemulsion and pure bull-frog oil). $100 \mu \mathrm{l}$ of the respective solutions was administered to each group for 4 consecutive days using the gavage technique. With the pre-treatment completed, the animals were anesthetized by inhalation for subsequent induction of the muscular lesion, with the inoculation of $20 \mu \mathrm{l}$ of formalin at $10 \%$ on the animals' gastrocnemius venter muscle. The lesion was evaluated from the muscle's horizontal extension (edema), using a digital metallic caliper ruler, positioned on the medium third of the animal's leg. The extension of the lesions was verified in the intervals of 5 minutes, 1, 2, 3, 4, 5 and 24 hours after the induction. For histological analysis, dissections of the gastrocnemius muscle were performed, to evaluate the presence of tissue injury. In parallel, samples of the animal livers were taken for evaluation of the parenchyma and analysis of signs of hepatotoxicity. As shown in Figure 2, when the microemulsion and the negative control (saline) groups are compared, a statistically significant difference $(p<0.001)$ can be observed. When the micro-emulsion and the FO (pure frog oil) groups are compared, no statistically significant difference is observed ( $p=0.9027$ ), showing that the micro-emulsion with oil concentration of $90 \%$ and the pure frog oil provide the same efficiency on the edema reduction. 
When the efficiency of the microemulsion is compared to the pure frog oil on the measurement intervals, both demonstrated to be effective up to the second hour, where greater statistical difference from the negative control group is observed, indicating lesser extension of the edema in both groups. No statistical difference was observed from the third to the twenty-fourth hour after the induction of the lesion.

Significant morphologic differences were observed on the analysis of the tissue samples from the microemulsion and pure frog oil groups. Discrete edema presence and small signs of tissue injury were observed on the microemulsion group (Figure 3A).

The analysis of the muscular tissue on the pure frog oil group showed relevant presence of edema and fragmentation of muscular fibers, denoting the installation of more evident muscle injury (Figure 3B).

Considering that the pure frog oil is rich in polyunsaturated fatty acids, which are metabolized by the liver, samples of the animals' livers in the microemulsion and pure frog oil groups were taken for histopathological analysis, with the intention to verify the existence of signs of hepatotoxicity. Undamaged hepatic lobes were observed on the hepatic tissue samples from the microemulsion group, with hepatocyte cords and capillary sinusoids positioned radially from the perimeter to the center of the lobe (Figure 4A).

The blood vessels appear congested with limpid light and preserved without any structural or morphological damage

Signs of injury on the lobes were observed on the hepatic tissue samples from the pure bullfrog oil group, as well as hepatocytes growth and signs of subscapular necrosis, injuries associated with the increased fat absorption by the animals, which denotes the hepatotoxic potential of the pure bullfrog oil (Figure 4B). The study was approved by the institution's ethics committee UNI-RN under n. protocol 001/2015.



Figure 1. Graphic representation of the construction on the phase diagram.

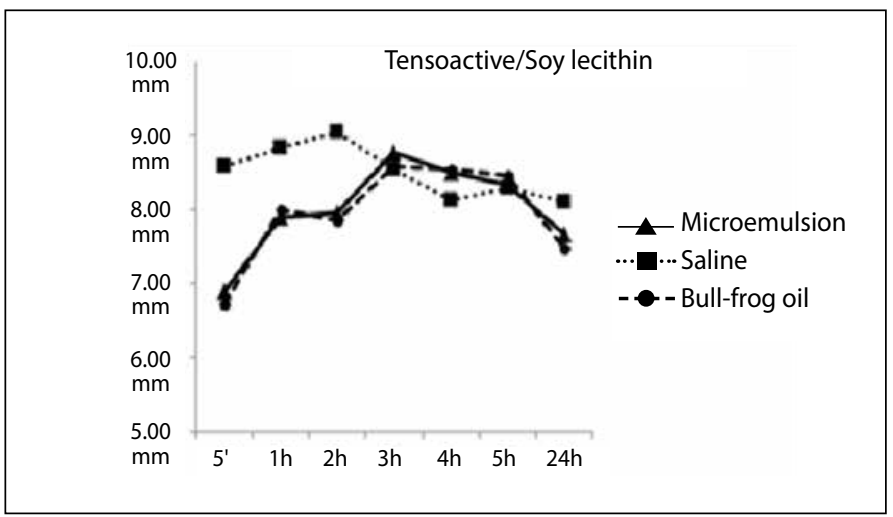

Figure 2. Evaluation of the edema through the measurement of the animal leg diameter on the microemulsion, saline and pure frog-oil groups.

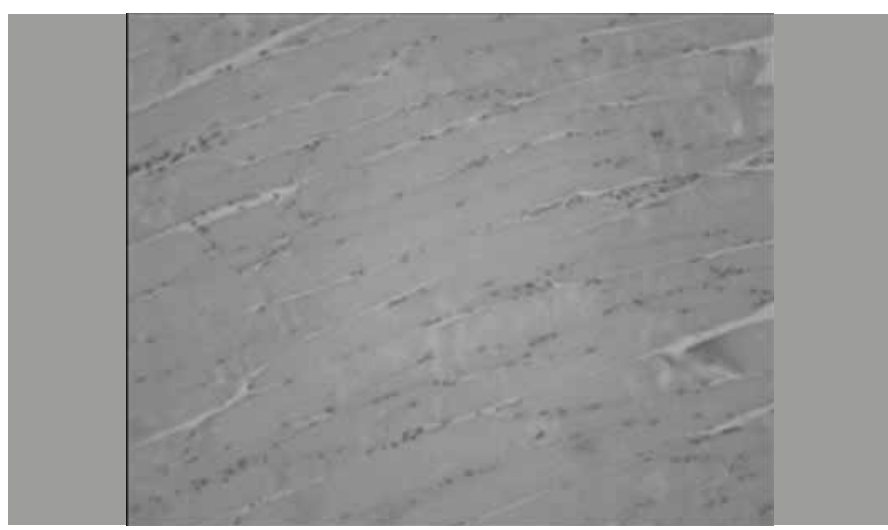

Figure 3A. Histologic section of muscle tissue on animal from the microemulsion group (10x magnification).

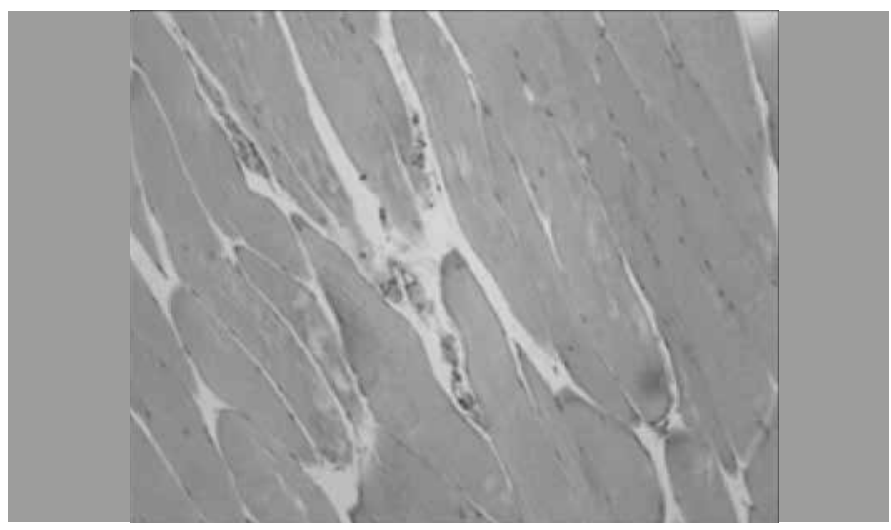

Figure 3B. Histologic section of muscle tissue on animal from the FO group (10x magnification).



Figure 4A. Histologic section of hepatic tissue on animal from the microemulsion group (100x magnification).



Figure 4B. Histologic section of hepatic tissue on animal from the FO group (100x magnification). 


\section{DISCUSSION}

Regarding the analysis of the edema caused by the muscular lesion induction in the animals, it was observed that both the microemulsion and the pure frog oil demonstrated similar biological activity, significantly reducing the edema in the first hours, when compared to the control group that received only saline solution. This indicates that both means of administration of the active ingredient, microemulsion and pure bullfrog oil, have potential to be used in the treatment of acute inflammation, as they act effectively in the first hours of the inflammatory response. However, in what concerns the histological analysis of the muscular tissue, it becomes evident that the muscle tissue sample from the animals that received the FO presented greater level of cellular infiltrate, edema along the tissue and fragmentation of the fibers. The animals treated with microemulsion presented discrete cellular infiltrate and edema, with no damage to the muscle fibers. This leads us to believe that, for some reason, the microemulsion acted protecting the muscle tissue, preventing an exacerbated inflammatory response. Studies show that, when not stimulated, the NF-kB factor is found in the cytoplasm, linked to an inhibitory protein, the $\mathrm{kBB}$. This complex prevents the translocation of NF-kB to the nucleus. Thus, both phosphorylation and degradation of $\mathrm{kB}$ are required for this translocation to occur and studies suggest that substances modulating the inflammatory response, whether of plant origin (herbal) or animal origin, such as bullfrog oil, act at this molecular level, still not thoroughly elucidated something that may be the subject of future research ${ }^{11}$.

The characterization of the muscular lesion is structurally given by the rupture of the myofilaments, mitochondrial abnormality and the sarcoplasmic reticule, discontinuity of the sarcolemma, hydro-electrolytic misbalance and cellular necrosis ${ }^{12}$ The histologic signs are related to the amount of injured fibers that is identified from some indicators, such as: cellular infiltrate (presence of inflammatory and/or satellite cells); basophilia (increase in ribosomic activity); centralized nuclei with prominent nucleoli and hyper concentration of myofilaments.

The metabolism of the oils happens in the liver and studies show that the excess of fatty acids may lead to hepatotoxicity, causing important functional changes in the organ. When the histology of the hepatic tissue was analyzed, it was observed that the hepatic tissue from the animals in the pure frog oil group displayed evident signs of injury, with alteration on the radial distribution and damage to the peripheral hepatocytes. The hepatic tissue for the animals from the microemulsion group showed no signs of injury or toxicity, giving the microemulsion the capacity of not overstressing the liver, regardless of its $90 \%$ oil content. Because it's a new system for drug release, the release of the substance and the metabolism of the oil were not sufficient to damage the liver. Since 1963, more than three million cases of hepatotoxicity from drugs have been notified by the World Health Organization (WHO). A research completed in four Brazilian medical centers (Hospital Português da Bahia, Hospital Sírio-Libanês, Hospital A. C. Camargo e Hospital das Clínicas da FMUSP) demonstrated that, from a total of 1,662 organ transplant cases studied, 84 were caused by fulminant hepatitis, 25 were induced by medication: antituberculosis (20\%), herbal (16\%), paracetamol (16\%), alphamethyldopa (16\%) ${ }^{13}$. The most relevant characteristic for the micro-emulsions is in their capacity of working as a reservoir for the slow release of the drug, providing an extended effect and avoiding a plasmatic concentration higher than necessary ${ }^{14}$. The number of pharmaceutical products based in this new molecule delivery system has significantly increased in the last few years and have a great tendency of growing further in the next few years ${ }^{15}$.

\section{CONCLUSION}

The authors concluded that a micro-emulsion composed by an oil phase of $90 \%$, aqueous phase of $5 \%$ and tensoactive phase of $5 \%$ and pure bull-frog oil present a good anti-inflammatory action in the first hours after the induction of the lesion, potentially indicating good therapeutic action on the treatment of acute inflammation, on the initial inflammatory response.

Thus, the results show great relevance, as they demonstrate that both micro-emulsion and the pure frog oil present good anti-inflammatory action when compared to a saline solution group (negative control). In addition, it was observed that the pure frog oil induced hepatic damage, which was not observed on the liver samples from animals treated with the microemulsion, proving the efficiency of the administration of medication through this means.

\section{ACKNOWLEDGMENTS}

The authors thank to "Centro Universitario do Rio Grande do Norte" (UNI-RN) for the availability of laboratory infrastructure, vivarium, as well as the materials used in the research. Also, they thank to "Conselho Nacional de Desenvolvimento Científico e Tecnológico" (CNPq) for the financial support for research. All authors read and authorized the publication of this manuscript.

All authors declare no potential conflict of interest related to this article.

AUTHORS' CONTRIBUTIONS: Each author contributed individually and significantly to the development of the manuscript. ALSD (0000-0002-8891-7619)* contributed to the preparation of the entire research project, writing and review of the manuscript, performing the experimental part, analysis of the histological slides. TNCD (0000-00033102-0912)* and MRP (0000-0001-8074-1359)* contributed to the preparation of the entire research project, data analysis, and writing of the manuscript. LBTSQ (0000-00022743-4576)* participated in performing the experimental part and statistical analysis. DFA (0000-0002-6206-2448)* participated in the statistical analysis. LMF (0000-00030270-8558)* participated in the accomplishment of the experimental part and aid in the preparation of the histological slides. *ORCID (Open Researcher and Contributor ID).

\section{REFERENCES}

1. Karasulu HY. Microemulsions as novel drug carriers: the formation, stability, applications and toxicity. Expert Opin Drug Deliv. 2008;5(1):119-35.

2. Tenjarla S. Microemulsions: an overview and pharmaceutical applications. Crit Rev Ther Drug Carrier Syst. 1999;16(5):461-521

3. Lopes VS. Óleo de Rã-Touro: um estudo físico-químico objetivando atividade farmacológica [dissertação]. Caicó, RN: Universidade Federal do Rio Grande do Norte, 2007.

4. Méndez E, Sanhueza J, Nieto S, Speisky H, Valenzuela A. Fatty acid composition, extraction, fractionation, and stabilization of bullfrog oil . J Amer Oil Chem Soc. 1998;75(1):79-83.

5. Silva LP, Miyasaka CK, Martins EF, Leite JR, Lacava ZG, Curi R, et al. Effect of bullfrog (Rana catesbeiana) oil administered by gavage on the fatty acid composition and oxidative stress of mouse liver. Braz J Med Biol Res. 2004;37(10):1491-6.

6. Calder PC. n-3 polyunsaturated fatty acids, inflammation, and inflammatory diseases. Am J Clin Nutr. 2006;83(6 Suppl):1505S-1519S

7. De Souza CT, Araujo EP, Bordin S, Ashimine R, Zollner RL, Boschero AC, et al. Consumption of a fatrich diet activates a proinflammatory response and induces insulin resistance in the hypothalamus. Endocrinology. 2005;146(10):4192-9.

8. Kiecolt-Glaser JK, Belury MA, Andridge R, MalarkeyWB, Glaser R. Omega-3 supplementation lowers inflammation and anxiety in medical students: a randomized controlled trial. Brain Behav Immun. 2011;25(8):1725-34.
9. Kelley DS. Modulation of human immune and inflammatory responses by dietary fatty acids. Nutrition. 2001;17(7-8):669-73.

10. Jung HS, Joo JD, Kim DW, In JH, Roh M, Jeong JT, et al. Effect of milrinone on the inflammatory response and NF-kB activation in renal ischemia-reperfusion injury in mice. Korean J Anesthesiol. 2014;66(2):136-42.

11. Perini JAL, Stevanato FB, Sargi SC, Visentaine RJE, Dalalio MMO, Matshushita M, et al. Ácidos graxos poli-insaturados n-3 e n-6: metabolismo em mamíferos e resposta imune. Rev Nutr. 2010;23(6):1075-86.

12. Oliveira CP, Coelho AM, Barbeiro HV, Lima VM, Soriano F, Ribeiro C, et al. Liver mitochondrial dysfunction and oxidative stress in the pathogenesis of experimental nonalcoholic fatty liver disease. Braz J Med Biol Res. 2006;39(2):189-94.

13. Warren GL, Summan M, Gao X, Chapman R, Hulderman T, Simeonova PP. Mechanisms of skeletal muscle injury and repair revealed by gene expression studies in mouse models. J Physiol. 2007;582(Pt 2):825-41.

14. Bittencourt PL. Epidemiologia da hepatotoxicidade por drogas. GED Gastroenterol Endosc Dig 2011:30(Supl.1):6-47

15. Lawrence MJ, Rees GD. Microemulsion-based media as novel drug delivery systems. Adv Drug Deliv Rev. 2000;45(1):89-121. 